\title{
The Ecological Significance on Primate Activity in Kimbi- Fungom National Park, Northwest Region, Cameroon
}

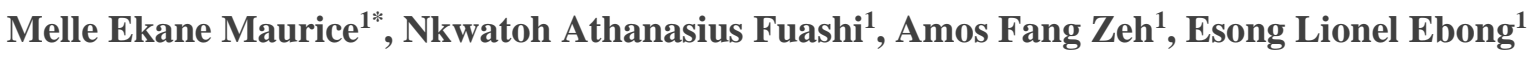 \\ ${ }^{1}$ Department of Environmental Science, University of Buea, P.O. Box 63, Buea, Southwest Region, Cameroon \\ *Corresponding Author: Melle Ekane Maurice, Department of Environmental Science, University of \\ Buea, P.O. Box 63, Buea, Southwest Region, Cameroon
}

\begin{abstract}
Nonhuman primates, our closest biological relatives, play important roles in the livelihoods, cultures, and religions of many societies and offer unique insights into human evolution, biology, behavior, and the threat of emerging diseases. They are an essential component of tropical biodiversity, contributing to forest regeneration and ecosystem health. The aim of this survey was to explore the ecological importance to the activities of the primates in kimbi-fungom national park. The research data was collected by laying 3-kilometer transects in the study area. The field data collection was on the activity of all the 6 primate species endemic in the national park and the weather conditions, seasonality, forest vegetation type, and the landscape were the ecological parameters considered for this study. The research data analysis was done by using SPSS version 20 , specifically chi-square and correlation statistical models were used to test the associations between the variables. The results revealed a significant relation between weather conditions and the primate activity, $\chi 2$ $=9.353 d f=10 P<0.05$. Moreover, there was an association between the primate species and the seasonal changes, $r=0.547 P<0.05$. In addition, the significant link between the vegetation and seasonal changes, $\chi 2$ $=7.16 \mathrm{df}=5 \mathrm{P}<0.05$ reflects the importance of these environmental parameters in the endemism and survival of the primate species in this area. Also, a significant association was recorded between primate activity and the forest vegetation types, $\chi^{2}=32.218 d f=25, P<0.05$. Furthermore, there was a significant link between landscape and primate activity, $\chi^{2}=16.234 d f=15, P<0.05$. This study, however, has revealed that the primate activity is strongly dependent on the ecology, hence, the destruction of the animal habitat through crop-farming is expected to create short and long-term wildlife conservation problems. Forcing crop-cultivation out of the national park area without an alternative provision of another farming area at the buffer zone would set in poverty, provoking a conservation conflict between the stakeholders and the local inhabitants. Any cultivation tradition of a protected area renders the wildlife population vulnerable to poaching, and automatically declines the animal population.
\end{abstract}

Keywords: Nonhuman primates, Tropical biodiversity, Ecological importance, Environmental parameters, Primate activity

\section{INTRODUCTION}

Primates are currently of great interest to conservation not only because of their potentials for acting as flagship species (Vargas et al. 2002) but also because half of the world's primate species are in trouble for a variety of reasons (Chapman and Peres 2001). While hunting is an important and widespread threat (Chapman et al. 1999a), the dependence of most primate species on tropical forests (Mittermeier and Cheney 1987) and the continuing devastation of these forests on a global scale (DeFries et al. 2002) make an understanding of primate habitat requirements, limitations, and flexibilities in relation to heterogeneity in primary and degraded forests paramount for conservation. Forest composition has often been studied as the major factor determining the abundance and distribution of forest dwelling primates. These studies have sometimes been conducted in reference to the changes initiated by logging (Chapman et al. 2000, Olupot 2000).

Primates are highly valued model animals, advancing our understanding of the evolutionary history of our species and providing insight into human behavior, cognition, parenting, cooperation, adult social bonds, forms of social conflict and resolution, learning and memory, and the evolution of tool use and language (Hare B.2011, \& Fernandez-Duque et al 2008). Although there exist important ethical issues that need to be considered when using primates in medical research (Phillips et al. 2014), primate models have furthered our understanding of atherosclerosis, respiratory diseases, HIV/AIDS, treatment 
responses to psychoactive drugs, psychopathologies, sociality, mental health disorders, communication, immunology, brain functioning, pharmacology, endocrine regulation of reproduction, genetics and genomics, and disease risk and parasite dynamics, among many other subjects (Phillips et al. 2014). Wild primate populations may hold valuable clues to the origins and evolution of important pathogens and processes of natural disease transmission by serving as sentinels for early disease detection, identification, and surveillance, thus benefiting humans. Because emerging infectious diseases also pose serious threats to both endangered and nonendangered primate species, studies of these diseases in one primate population may benefit research.

Deforestation, hunting, illegal trade, and wood extraction are leading to a worldwide impoverishment of primate fauna. Drivers of primate loss are dynamic and interact with each other at local, regional, and global scales, leading to a trajectory of bio-simplification that is most keenly felt as marked reductions in population sizes and, all too soon, extinctions. The global scale of primate population declines and the predicted increase in the intensity of major anthropogenic threats suggest that conserving wild primates is an immediate but daunting challenge (Phillips et al. 2014). Without widespread systemic changes in human behavior, populations will continue to decline over the next few decades, with species currently listed by the IUCN as threatened becoming extinct and species now classified as near threatened or least concern facing increased extinction risk. Many primates are iconic (for example, gorillas, chimpanzees, orangutans, spider monkeys, and lemurs), but given the scale of their decline, it is clear that neither their charisma nor their flagship status is sufficient to safeguard them from the threat of human-induced extirpation throughout their native ranges. Extinction rarely results from deficient scientific knowledge of the steps required to protect the species. Instead, it is embedded in political uncertainty, socio-economic instability, organized criminality, corruption, and policies that favor short-term profits over long-term sustainability (Phillips et al. 2014).

Primates living in tropical forests regularly form large mixed-species associations, often containing several different species. The Taï forest of Ivory Coast is a particularly striking example with six arboreal simian species (Cercopithecus diana, C. campbelli, C. petaurista, Colobus badius, C. polykomos, C. verus), as well as two terrestrial ones (Cercocebus atys, Pan troglodytes) coexisting at high densities of up to more than two groups per square kilometer (Zuberbühler and Jenny, 2002). The tacit assumption is that these high densities in primate biomass are made possible by species-specific ecological adaptations, in which species exploit a subsegment of the available resources only. Niche separation is thought to decrease interspecies competition and make coexistence of closely related species possible (Korstjens, 2001; McGraw, 2000; Wolters and Zuberbühler, 2003;). Although niche separation explains the co-existence of the seven different monkey species in the Taï forest at high densities, it has left occasional reports of an eighth species, the putty-nosed monkey, largely unexplained.

Long-term deforestation has resulted in the fragmentation of $58 \%$ of subtropical and $46 \%$ of tropical forests (Haddad et al 2015, Mercer 2017), forcing primates to live in isolated forest patches, including protected areas. This has led to decreasing numbers, population restructuring, and the loss of genetic diversity, as shown for pied tamarins (Saguinus bicolor), northern muriquis (Brachyteles hypoxanthus), Udzungwa red colobus monkeys (Piliocolobus gordonorum), several species of Chinese colobines (Rhinopithecus and Trachypithecus), Cross River gorillas (G. gorilla diehli), and Bornean orangutans (Meijaard, et al 2011, Silveira, et al. 2016). Edge effects predominate in many areas of disturbed forests, exacerbating habitat degradation (Haddad et al 2015). Agricultural expansion as well as legal and illegal logging cause further desiccation of vegetation, and human-induced forest fires devastate large areas in primate range regions yearly, resulting in increased tree mortality and losses of up to one-third of canopy cover (Gouveia, et al. 2014, Meijaard et al.2012). Although the effects of habitat loss, fragmentation, and degradation upon primates are mediated by variations in species-specific traits (rarity, trophic levels, dispersal mode, reproductive biology, life history, diet, and ranging behavior), the common response across taxa is population decline. Some primates are more behaviorally and ecologically resilient than others when faced with habitat loss, fragmentation, and degradation. Bornean orangutans, for example, can survive, at least temporarily, in logged forests, Acacia plantations, and oil palm plantations (Jaman, and Huffman 2016). Baboons (Papio), Hanuman langurs (Semnopithecus), and macaques (Macaca) are particularly adaptable and can survive even in urban areas (Krief, et al.2014). Chimpanzees appear to evaluate risks when crop-foraging and adjust their foraging patterns in deciding whether to exploit fragmented forests near humans (Hickey et al.2013). Bonobos tend to avoid areas of high human activity, fragmented forests, or both, and although this may suggest flexibility, the presence 
The Ecological Significance on Primate Activity in Kimbi-Fungom National Park, Northwest Region, Cameroon

of humans appears to significantly reduce their access to potentially available habitat (Hickey et al. 2013). Still, persistence in isolated forest fragments, logged forests, agro-ecosystems, and urban areas is unlikely to be a sustainable option for most species due to hunting, further habitat reduction and fragmentation, reduced carrying capacity, parasite and disease transmission from humans and domestic animals, dog predation, human-primate conflict due to crop raiding, isolation, and continued changes in land use (Estrada et al.2012).

\section{Materials AND Methods}

\subsection{Description of the Study Area}

Kimbi-Fungom National Park (KFNP) is located between latitude $6.5^{\circ}-6.9^{\circ} \mathrm{N}$ and longitude $9.8^{\circ}-10.5^{\circ}$ $\mathrm{E}$ in the Northwest Region of Cameroon and covers a total land surface area of 95,380 hectares (Fig.1). This national park is situated within three administrative divisions in the Northwest Region of Cameroon; Menchum, Boyo and Dongo Mantung (Tata 2015). The region experiences two seasons, a long rainy season from mid-March to mid-November, and a short dry season from mid-November to mid-March. The wettest months are July, August and September and the driest months being January and February. The national park drainage system includes Kimbi, Katsina Al, and Kendassamen rivers. The soil types in this area include acrisols, andosols (Black soils of volcanic landscapes), and ferrasols (Birdlife, 2010). The vegetation is principally lowland tropical rainforest at the Fungom low altitude area of the national park, which is progressively transformed into a savanna landscape towards its northern region. The national park also harbors many wildlife species; primates, ungulates, carnivores, a host of rodents, reptiles and amphibians. Endangered species such as Chimpanzee (Pan troglodytes ellioti) and pangolins (Smutsia gigantea) are found in the park. Other primates include mona monkeys (Cercopithecus mona), putty-nosed monkeys (cercopithecus nictitans) and baboons (Papio anubis and Papio. cynocephalus).

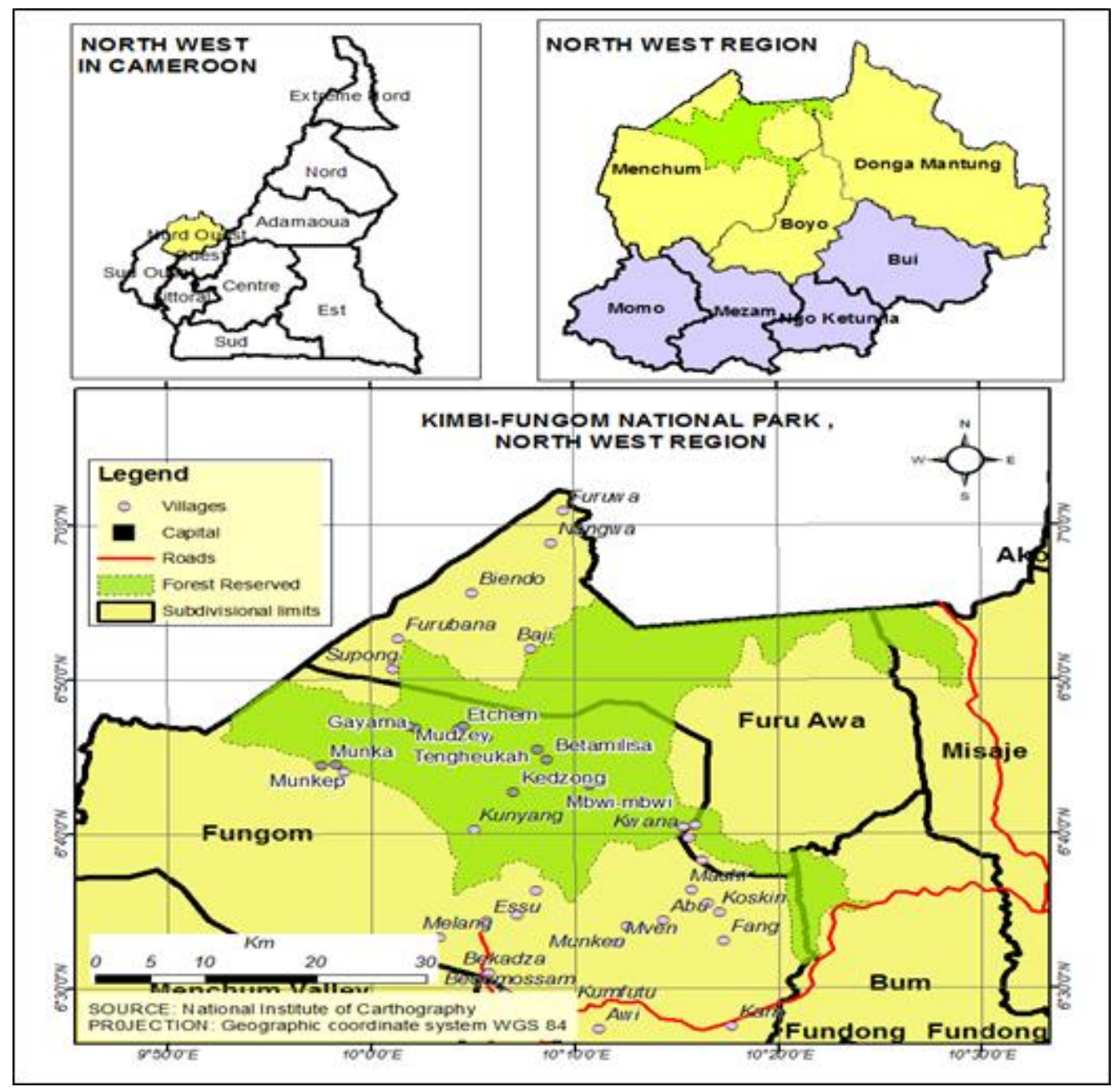

Figure1. Kimbi Fungom National Park (KFNP) map 


\subsection{Research Data Collection}

The research data collection started prior to the pilot study that witnessed the testing of research tools. The starting point of each 3-kilometre transect was determined systematically on a gridded map of the study area. The average distance between any two line transects was $3 \mathrm{~km}$. Line transect surveys began early in the morning around 6:30 a.m. and lasted on average for 5-6 hours. Primate calls were used to access the presence and type of primate species in the vicinity of the transects. However, only direct sightings of primates were recorded. All sightings where estimation of group size was difficult to assess were disregarded. When primates were encountered, the number of individuals (group size), species, time, GPS (Garmin GPS map 62) location, and perpendicular distance to primate(s) were recorded. The distance along transects was measured with a tape measure. The perpendicular ground distance from the transect center line to an estimated central point directly beneath where the primates were initially sighted was also measured using a tape measure. Binoculars were used when necessary to confirm species identity.

\subsection{Data Analysis}

The research data was analyzed using SPSS version 20, specifically chi-square and correlation statistical models were used to the test association between the variables. The social behaviors of the various primate species were tested on weather condition, seasonality, landscape, and the vegetation type. The results of the study was displayed in tables and figures

\section{RESUlTS}

The study has shown a significant relation between weather conditions and the animal activity, $\chi^{2}=$ $9.353 \mathrm{df}=10 \mathrm{P}<0.05$ (Fig. 2). Though, the animal activities were observed in all the weather conditions, the cloudy and sunny weather conditions were more favored than the wet. During a rainy weather the animals were not easily observed since they would run into shaded areas for a cover, preventing the researchers from activity observation. A heavy rainy weather halted most of their activities, as the animals were observed rushing for food just after the rains. On the other hand, observing the activities of some wildlife species during the rain is not easy. In this study, the animals were not easily observed, and even when observed they were not active.

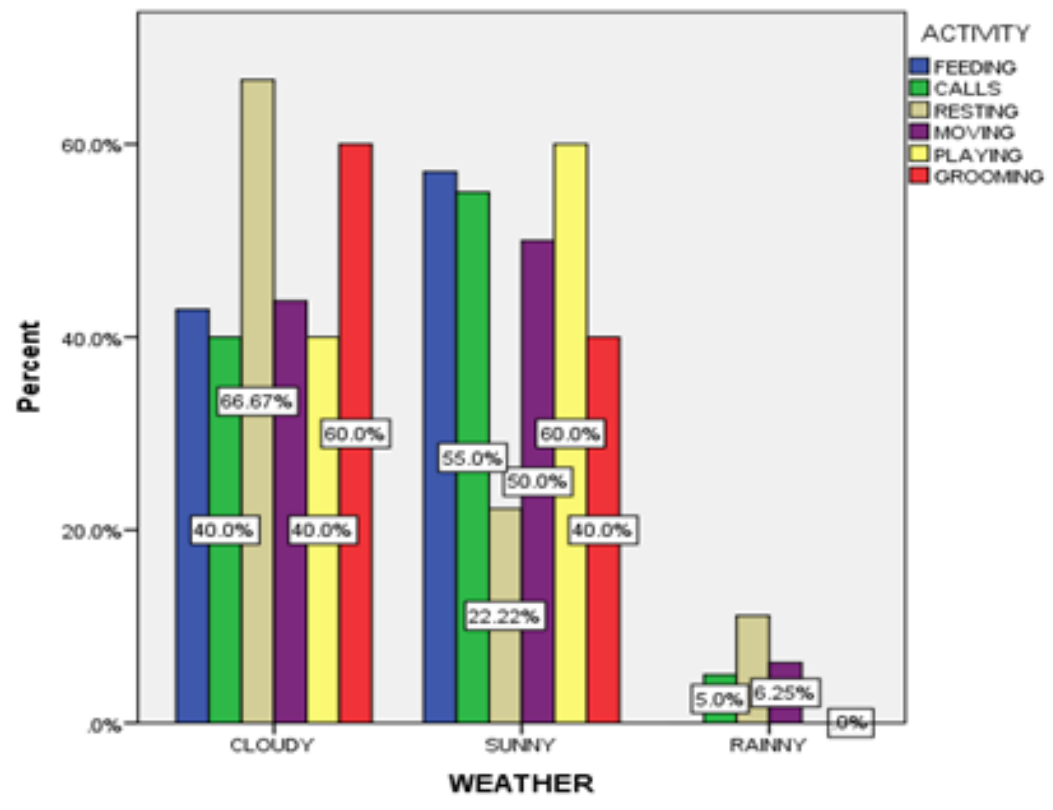

Figure2. Weather condition and Animal activity

There was association between the primate species and the seasonal changes, $r=0.547 \mathrm{P}<0.05$ (Fig. 3 ). Seasonality is one the major ecological parameters that determine the survival of wildlife in the wild. For this reason wildlife adaptation to seasonal conditions has contributed to their endemism and distribution worldwide. In this study, the primate activity level was observed highest in the dry season than the wet season in all the primate species. The dry season has a dry weather condition, facilitating the movement and feeding activities of wildlife. Though, there is less food availability in this season, 
the comfortable weather condition determines their activity profile in some cases. There is also a possibility that the animals will easier be spotted in a bright weather that the wet. The vegetation cluster or cover in the wet season hides the animals preventing them to be easily observed by the researchers. It is also known that wildlife cover longer distances in the dry season looking for food than the wet.

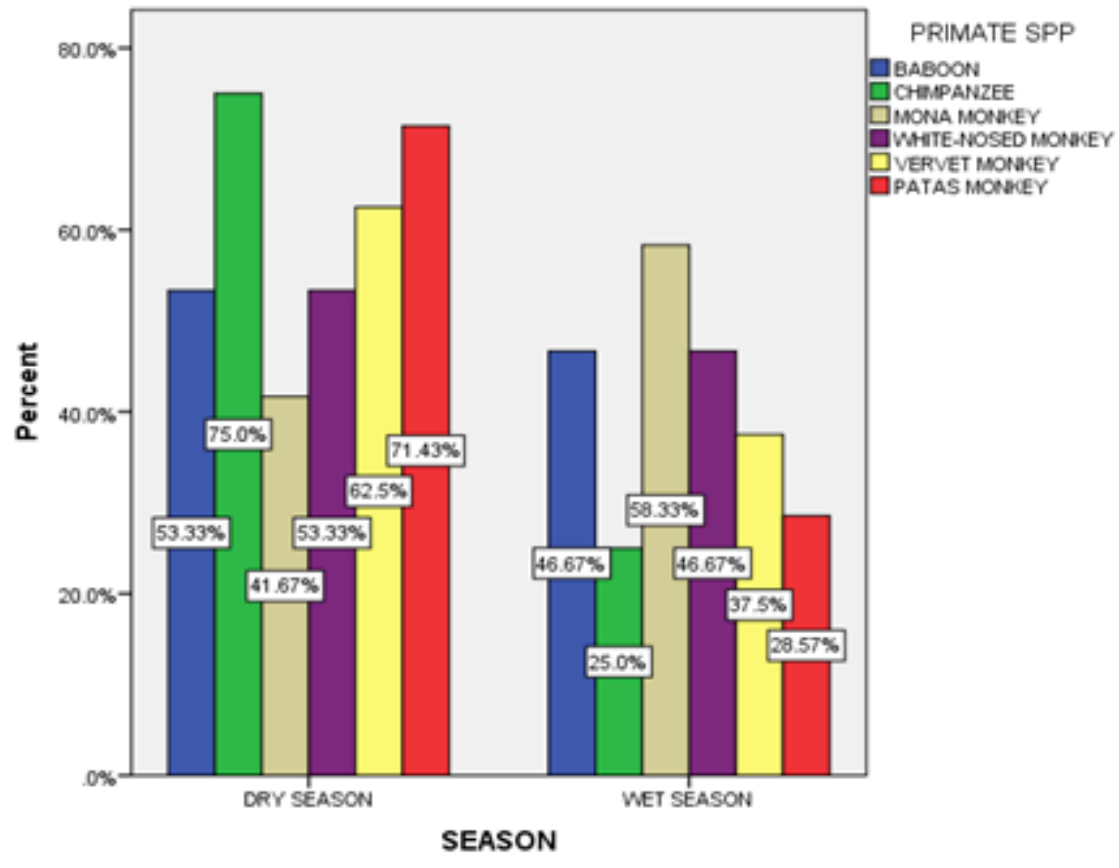

Figure3. Primate species and season changes

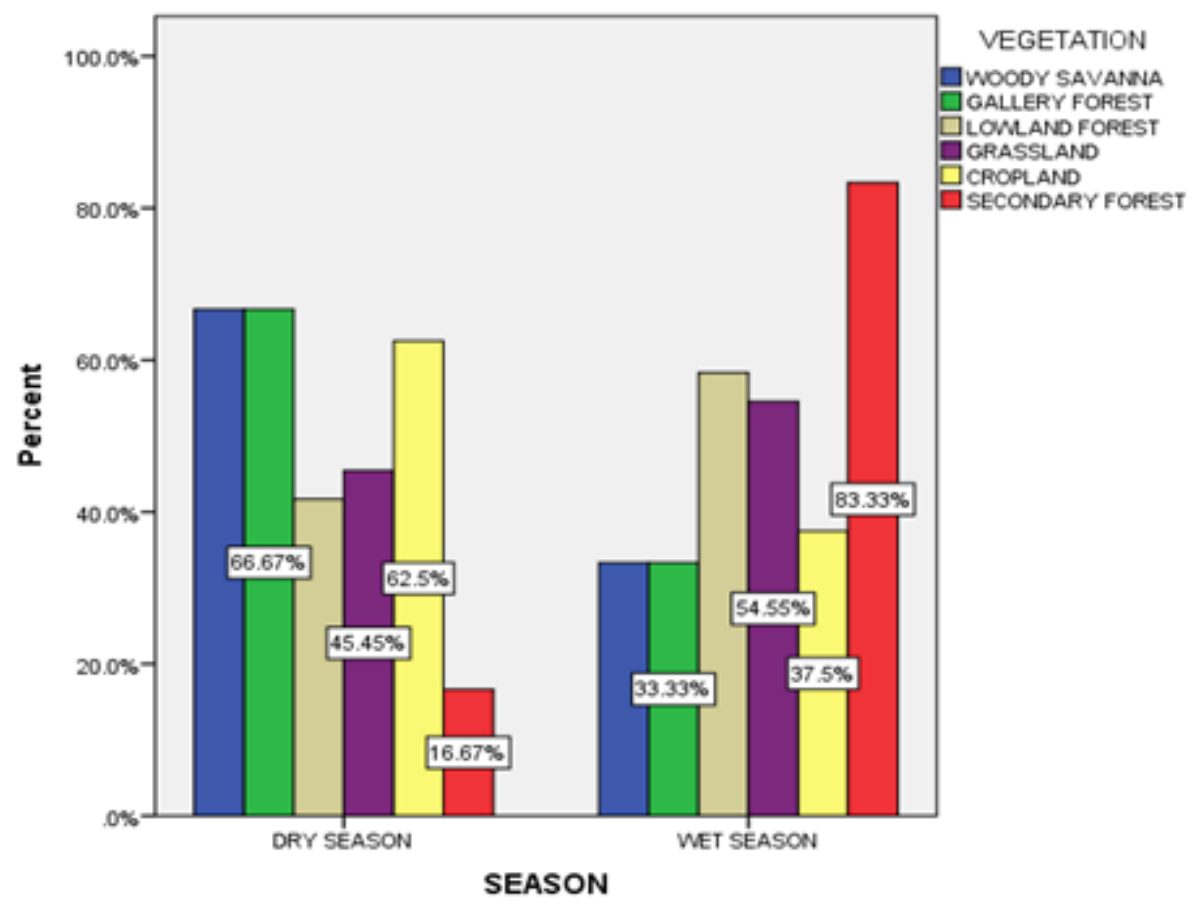

Figure4. The vegetation type and seasonality

The significant link between the vegetation type and seasonal changes, $\chi^{2}=7.16 \mathrm{df}=5 \mathrm{P}<0.05$ (Fig. 4 ) reflects the importance of both environmental parameters in the endemism and survival of wildlife species in the wild. Both seasons witnessed the activity of all the primate species in the national park. The animals were observed roaming from one vegetation type to another looking for food, and the vegetation with abundant food resources would probably determine their activity duration for the day. A poor habitat in wildlife food would never keep wildlife activity for a longer period. The secondary forest vegetation was observed with a high animal activity in the wet season $83.33 \%$ because of its 
richness in primate food during this season. Also, in the dry season the gallery and woodland savanna ecosystems were observed with a lot of animal activity $66.67 \%$ because of the richness in food resources and shade provision ability for the animals.

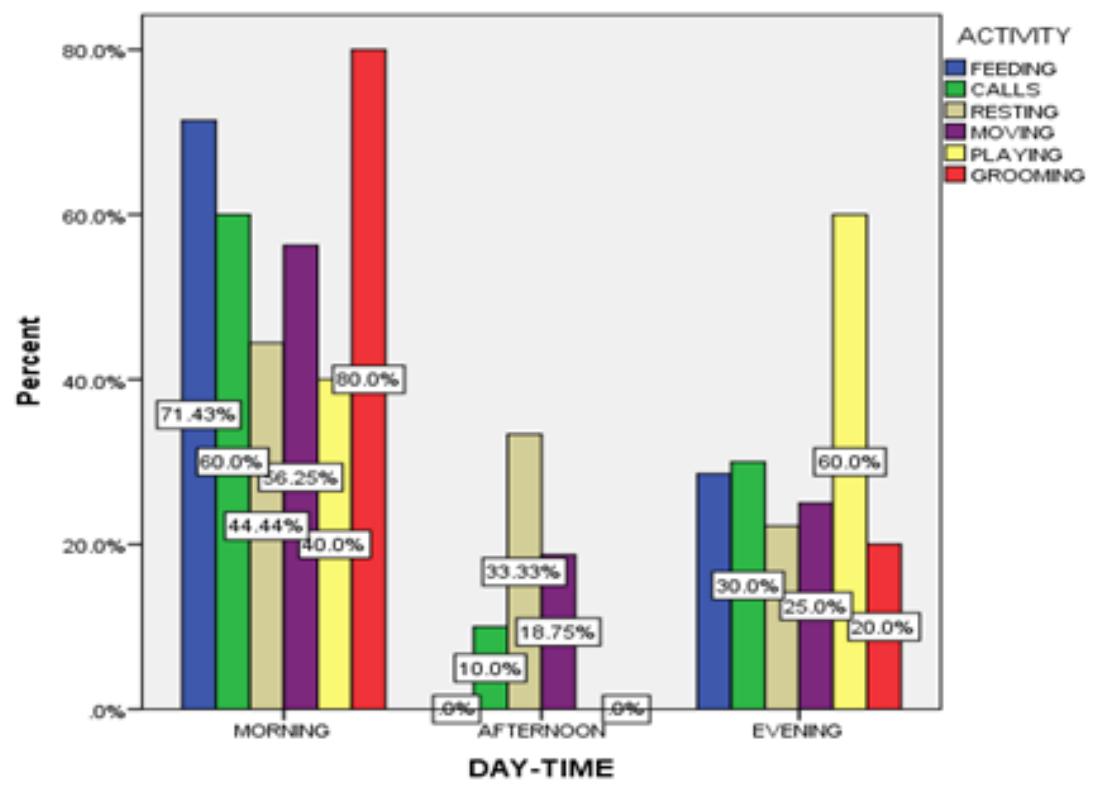

Figure5. The animal activity and the day-period

A significant association between the animal behavior and the day-period $\chi^{2}=15.822 \mathrm{df}=10, \mathrm{P}<0.05$ (Fig.5) has shown the photo-period witnessing a spectrum of animal behaviors. However, the morning period stands highest in the animal activity profile while the afternoon period has shown the least. The morning period of the day is fresh for wildlife, especially the vegetation; hence, most primate species and other wildlife use this period to increase social activities like feeding and foraging. In most areas in sub Saharan Africa, the morning period of the day is characterized with lower environmental temperature, a physiological advantage for normal body metabolism for the animals. During this period their activities were observed with a gradual increase towards the mid-day. However, a decrease in animal activity observed at mid-day was believed to be due to the increase in temperature, a disadvantage to the animal metabolic reaction, resulting to more rest as witnessed by this study. The evening period experienced a gradual activity increase because of the decrease in environmental temperature.

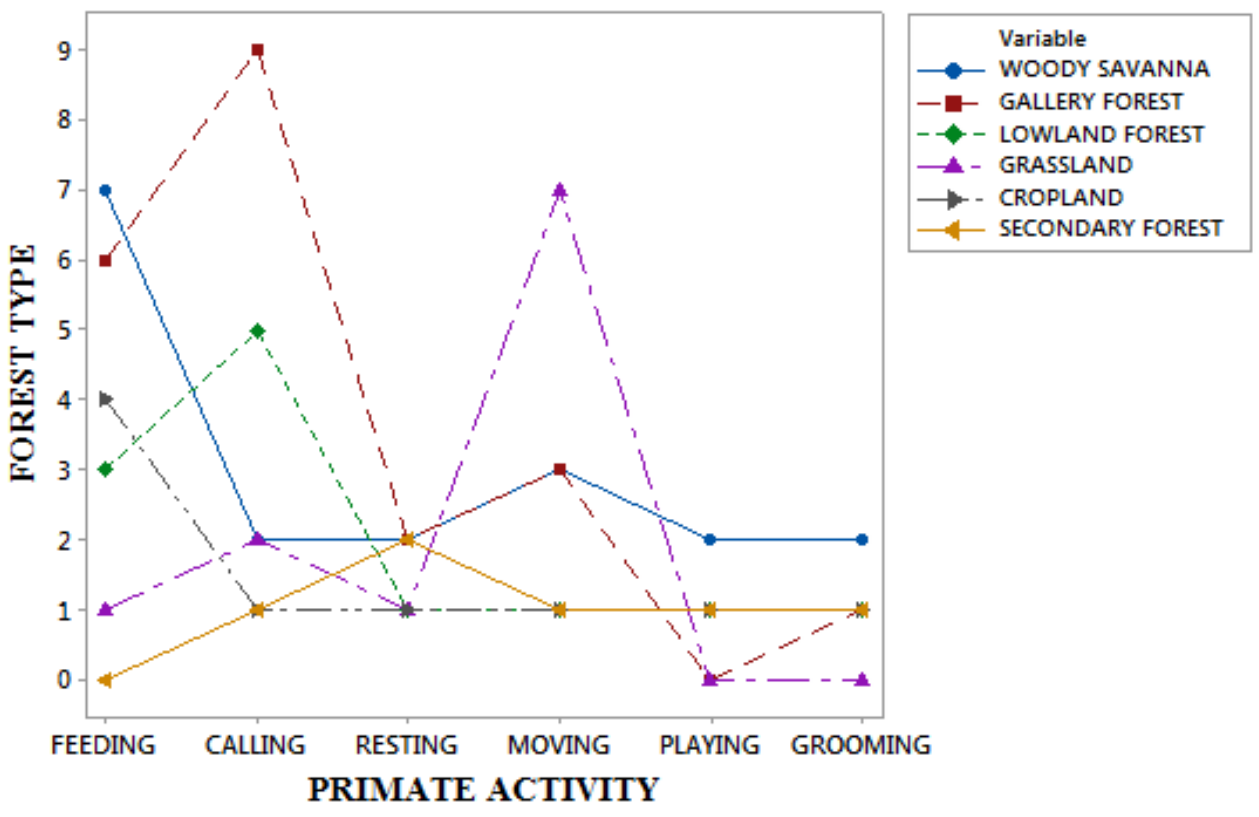

Figure6. The primate activity and the forest vegetation type 
The Ecological Significance on Primate Activity in Kimbi-Fungom National Park, Northwest Region, Cameroon

A significant association recorded between primate activity and the forest vegetation types, $\chi^{2}=32.218$ $\mathrm{df}=25, \mathrm{P}<0.05$ (Fig.6) has shown the need and importance of forest vegetation to wildlife survival in this national park. The animals were observed making use of all the vegetation types, with feeding and calling behaviors recording the highest. The gallery and grassland vegetation areas were observed with the highest activities. Nonetheless, the vegetation richness in wildlife food determines the frequency of animal activity, the reason which some forest vegetation locations of this national park experienced more animal activity comparatively.

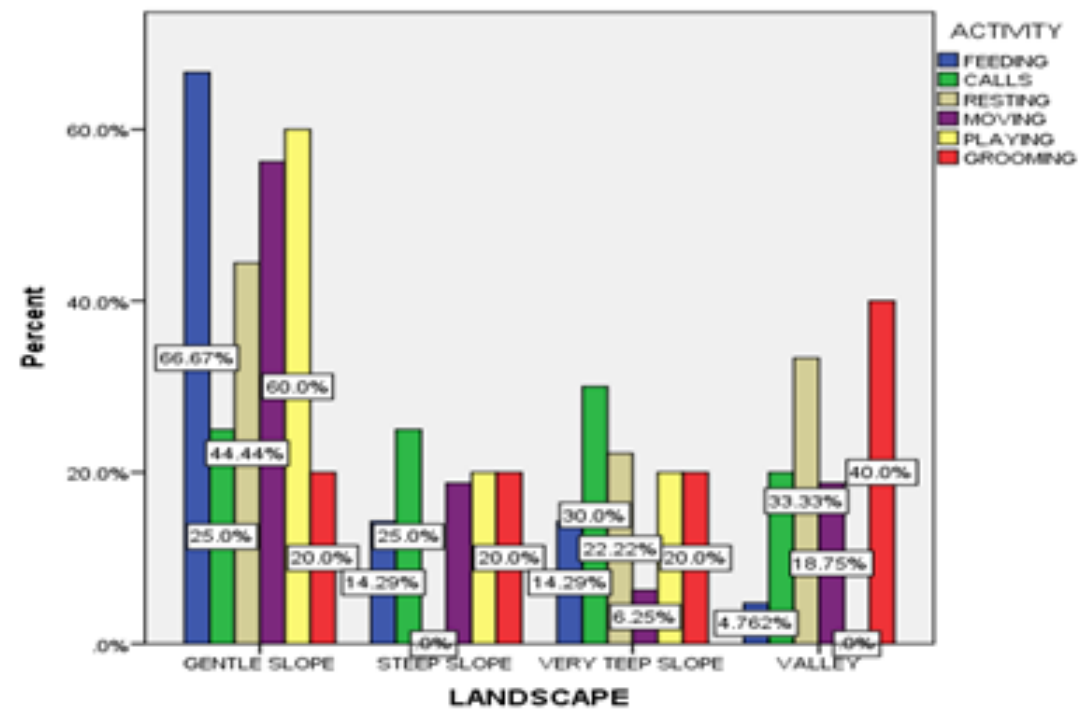

Figure7. The landscape and animal activity

The results have shown a significant link between landscape and primate activity, $\chi^{2}=16.234 \mathrm{df}=15$, $\mathrm{P}<0.05$ (Fig. 7). The landscape of the area was also observed hosting all the animal activities, but highest in the gentle slope areas, which had much food for the animals. Animal activity decline was witnessed in steep and very steep slopes because these areas were not only food deficient but also difficult for wildlife movement. The type of landscape in a protected area or a forest could determine the type of animal species to inhabit. In areas where landscape is characterized with cliffs only birds might sometimes be observed inhabiting these areas. Since cliffs and steep slopes can hardly keep primate populations, the tendency for the animals to frequent lower areas rich in food resources is high.

Table1. Association between habitat-type and species distribution

\begin{tabular}{|c|c|c|c|c|c|c|c|}
\hline \multirow[t]{2}{*}{ Species } & \multicolumn{6}{|c|}{ Habitat type } & \multirow[t]{2}{*}{ Total } \\
\hline & $\begin{array}{c}\text { Woody } \\
\text { savanna }\end{array}$ & $\begin{array}{c}\text { Gallery } \\
\text { forest }\end{array}$ & $\begin{array}{c}\text { Low land } \\
\text { forest }\end{array}$ & Grassland & $\begin{array}{l}\text { Crop } \\
\text { land }\end{array}$ & $\begin{array}{c}\text { Secondary } \\
\text { forest }\end{array}$ & \\
\hline \multirow{2}{*}{ Baboons } & 5 & 1 & 0 & 2 & 1 & 0 & 9 \\
\hline & $38.5 \%$ & $6.2 \%$ & $0.0 \%$ & $28.6 \%$ & $25.0 \%$ & $0.0 \%$ & $17.6 \%$ \\
\hline \multirow{2}{*}{ Chimpanzee } & 0 & 2 & 0 & 0 & 0 & 1 & 3 \\
\hline & $0.0 \%$ & $12.5 \%$ & $0.0 \%$ & $0.0 \%$ & $0.0 \%$ & $33.3 \%$ & $5.9 \%$ \\
\hline \multirow{2}{*}{ Mona monkey } & 0 & 4 & 6 & 0 & 0 & 1 & 11 \\
\hline & $0.0 \%$ & $25.0 \%$ & $75.0 \%$ & $0.0 \%$ & $0.0 \%$ & $33.3 \%$ & $21.6 \%$ \\
\hline \multirow{2}{*}{$\begin{array}{l}\text { White nose } \\
\text { monkey }\end{array}$} & 0 & 8 & 2 & 0 & 2 & 1 & 13 \\
\hline & $0.0 \%$ & $50.0 \%$ & $25.0 \%$ & $0.0 \%$ & $50.0 \%$ & $33.3 \%$ & $25.5 \%$ \\
\hline \multirow{2}{*}{ Vervet monkey } & 3 & 1 & 0 & 3 & 1 & 0 & 8 \\
\hline & $23.1 \%$ & $6.2 \%$ & $0.0 \%$ & $42.9 \%$ & $25.0 \%$ & $0.0 \%$ & $15.7 \%$ \\
\hline \multirow{2}{*}{ Patas monkey } & 5 & 0 & 0 & 2 & 0 & 0 & 7 \\
\hline & $38.5 \%$ & $0.0 \%$ & $0.0 \%$ & $28.6 \%$ & $0.0 \%$ & $0.0 \%$ & $13.7 \%$ \\
\hline \multirow{2}{*}{ Total } & 13 & 16 & 8 & 7 & 4 & 3 & 51 \\
\hline & $100.0 \%$ & $100.0 \%$ & $100.0 \%$ & $100.0 \%$ & $100.0 \%$ & $100.0 \%$ & $100.0 \%$ \\
\hline
\end{tabular}

However, the distribution of primate species across the national park on various habitat types; woody savanna, gallery forest, lowland forest, grassland, cropland, and secondary forest revealed $17.6 \%$ for baboons, $5.9 \%$ for chimpanzees, $21.6 \%$ for mona monkeys, $25.5 \%$ for white-nosed monkey, $15.7 \%$ for vervet monkeys, and $13.7 \%$ for patas monkey respectively (Tab. 1). The primate species and population 
distribution in the national park is not restricted to specific forest-type, even the farming areas were observed with monkeys.

\section{DISCUSSION}

A fundamental issue in ecology is determining factors that regulate animal abundance. A variety of potential factors have been proposed, including external factors such as food resources, weather, predation and disease, and internal conditions such as territoriality and aggressive behaviors (Boutin 1990). The importance of understanding determinants of animal abundance has become increasingly vital as ecologists are asked to apply their knowledge to develop informed management plans for endangered or threatened species. However, understanding and predicting factors that determine the abundance of particular species have proven extremely difficult, and thus there are few general hypotheses addressing this topic. Studies of folivorous primates are a notable exception. Milton (1979) proposed that year-round availability of digestible mature leaves, which are used by colobus monkeys when other more preferred foods are unavailable, limits colobine populations (McKey 1978). Therefore, if easily digestible mature leaves are plentiful in an area when other more preferred foods are lacking, the site may support a relatively large population of colo- bines (Davies 1994). By measuring overall mature leaf quality as the ratio of protein to fibre, several sub- sequent studies have found positive correlations between colobine biomass and this index of leaf quality (Waterman et al. 1988; Oates et al. 1990; Chapman et al. 2000).

Spatial ecology has been a central theme in primatology for more than seven decades (Carpenter 1940). Since then extensive variability in ranging patterns has been documented across the primate order (De Luca et al 2003) both among (interspecific) and within (intraspecific) species. At the broadest level the variation in spatial ecology can be explained by differences in ecological niche occupation, foraging strategies (Arrowood et al. 2003; Strier 2007) and the inherent constraints imposed on primates living under the different ecological conditions. At a finer scale, ranging pattern variation stems from the intrinsic and extrinsic factors operating on primate groups. For all primates, spatial ecological patterns are a function of ecological and social factors (Harvey and Clutton-Brock 1981) that operate on spatial and temporal scales. Ecological factors that affect ranging patterns and dictate the intensity to which certain areas of the landscape are used (Altmann and Altmann 1970) include: water availability (Altmann and Altmann, 1970), sleeping site location (Zinner et al. 2001; Zhou et al. 2007), and the availability, distribution and quality of food sources (Ganas and Robbins 2005; Li and Rogers 2005). Ranging patterns are further affected by climatic variability in rainfall (Higham et al. 2009), temperature (Yang 2003) and day length (Hill et al. 2003), all of which have a direct bearing on primate biology (Hill et al. 2003, 2004; Dunbar 1993), affecting primates indirectly through their influence on natural resources (Bronikowski and Altmann 1996). At a community level, the ecological factors affecting primate spatial ecology are intra-specific relationships (Goodall 1986; Fashing 2001), interspecific associations (Holenweg et al. 1996), and predation pressure (Treves 2002; Matsuda et al. 2009), perceived predation risk (Cowlishaw 1997) and parasite avoidance (Hausfater and Meade 1982). Of these influential ecological factors, food availability and distribution offers the best explanation for the variation seen in primate ranging patterns (Bennett 1986).

On a spatial scale, primates who rely on widely dispersed food sources with unpredictable availability are predisposed to travelling farther each day and covering larger ranges than primates who feed on evenly distributed and reliably available food sources (Oates 1987). Similarly, on a temporal scale, seasonal shifts in food availability and distribution may result in primate troops travelling farther during periods of food scarcity than periods of food abundance (Stevenson 2006; Buzzard 2006). Primate spatial ecology is also influenced by troop size (Ostro et al. 1999; Ganas and Robbins 2005), troop spread (Treves et al. 2001) and intra-group relationships (Robbins and McNeilage 2003). Troop living may confer the benefit of reduced predation risk to individuals, however intra-group feeding competition, which can hinder reproduction and compromise survival, is widely recognized as the greatest corresponding cost (Chapman and Chapman 2000; Ganas and Robbins 2005). As primate troop sizes increase so scramble and or contest competition increase (Isbell and Young 1993; Wrangham et al. 1993), forcing larger troops to cover larger areas to obtain enough food for all troop members (Wrangham et al. 1993; Chapman et al. 1995; Janson and Goldsmith 1995). Thus, an increase in troop size should result in a corresponding increase in day range length and home range size (Chapman and Chapman 2000). This pattern has been widely, but not consistently, found in studies of primates (Gillespie and Chapman 2001). 
Primates are a taxonomic group for which diversity and distribution patterns are relatively well understood (Lehman \& Fleagle 2006; Rylands; Mittermeier et al. 2013). Primate diversity has been related to different environmental drivers in distinct locations and regions, but a comprehensive global analysis of these drivers is not available. Regional patterns of primate species richness have been attributed, for example, to the variation in precipitation rates, either directly or as a proxy for productivity (Gavilanez \& Stevens 2013). While precipitation levels have been linked to species richness through tolerance optima (Fischer 1960), the productivity hypothesis proposes that areas with increased productivity can supply resources for more individuals and thus, more species (Wright 1983). In fact, climate should limit the distribution of non-human primates at high latitudes, reflecting the origin of the clade under conditions similar to those found in present-day tropical regions (Fleagle \& Gilbert 2006). Variation in vertical forest structure, for example, has been attributed to both plant productivity (as determined primarily by the amount of rainfall; Woodward 1987) and the incidence angle of solar radiation (Terborgh 1985), thus showing a clear latitudinal gradient. Owing to the close association of primates with tropical forests (Sussman 1991), the structure and distribution of these forests would likely be a good indicator of the diversity of the habitats or microhabitats available for primates, with more species being found in structurally more complex forests. By contrast, the simplification of forest structure - through habitat fragmentation, for example - will have a negative effect at the population or community levels (Marsh 2003; Marsh \& Chapman 2013), so that a reduction in primate species richness following the intensification of habitat impacts can be predicted.

Non-human primates (referred to hereafter as 'primates') present one of the greatest and most complex conservation challenges at the human-wildlife interface. The geographical overlap (sympatry) of humans and primates, which is widespread across Africa, Madagascar, Asia and Central and South America, is most likely attributable to an evolutionary convergence of ecological requirements (Sponsel et al. 2002). However, according to the most recent IUCN red data list, anthropogenic habitat disturbance is the primary cause for $92 \%$ of all primate species being classified as endangered (IUCN 2010). Habitat loss associated with deforestation, agricultural encroachment and urbanization poses a direct threat to specialist primates whose survival is reliant on access to habitat and food found only in narrow ecological niches (Peres 1993). The effects of habitat change are less direct for generalist primates whose behavioral and dietary flexibility affords them the potential not only to benefit from, but also to thrive on anthropogenic habitat disturbance (Strum 2010). However, for generalists the feeding benefits associated with human-modified habitats most commonly come at the cost of humanprimate conflict (Else 1991).

Conflict has characterised the relationship between humans and wildlife throughout history (Heydon et al. 2010). However, the transformation of global landscapes from predominantly wild to predominantly anthropogenic over the last three centuries (Ellis et al. 2010) has brought competition between humans and wildlife for space and resources to unprecedented levels (Bulte and Rondeau 2005; Woodroffe et al. 2005). Associated increases in human-wildlife conflict now pose one of the greatest threats to the persistence and survival of many animal species (Dickman 2010) and finding ways to manage and resolve these conflicts is vital for their long-term conservation (Heydon et al. 2010). A multitude of methods are employed to reduce human-wildlife conflict including the management of animal numbers (e.g., culling, translocation) and the separation of wildlife from humans using a host of deterrents (e.g., electric fences, herders, repellents; Dickman 2010). However, there is rarely a single panacea to the problem; instead a variety of strategies typically need to be implemented for successful conflict mitigation (Distefano 2005). Humans have occupied almost every corner of the earth's surface for 10 000 years. However, the last three centuries have seen an unprecedented expansion of the human population and the transformation of global landscapes from predominantly wild to predominantly human-modified (Ellis et al. 2010). The proliferation of humans is credited to our ability to simplify ecosystems through habitat homogenization, food web simplification, and nutrient input. However, the concomitant conversion, compression and fragmentation of natural land is considered the leading cause of extinction across all other species, with many wildlife adversely affected by the associated impacts including changes to habitat and resource availability, geographic isolation (Cushman 2006), increased disease emergence (Daszak et al. 2001) and increased conflict with humans (Bulte and Rondeau 2005; Woodroffe et al. 2005). 


\section{CONCLUSION}

Primates are of central importance to tropical biodiversity and to many ecosystem functions, processes, and services. In addition, they are our closest living biological relatives, offering critical insights into human evolution, biology, and behaviour and playing important roles in the livelihoods, cultures, and religions of many societies. Unsustainable human activities are now the major force driving primate species to extinction. This study has revealed the dependency of the primates on the ecology of the national park; however, many questions are raised if the un-going anthropogenic scale of destruction of the landscape through farming and hunting would survive the wildlife population for up to a decade. Almost all the primate species of this national park are arboreal, but the scale of tree-felling for house construction, definitely is further escalating forest or primate habitat destruction to a large irreversible proportion. Primates in degraded forests would face nutritional shortfalls and lower gut microbial diversity. They also show an increased prevalence of parasites and pathogens due to their habitat loss. Our biological closeness to the primates is known to have been the entering point of most zoonotic viral, parasitic, bacterial, and fungal infections to humans. Unfortunately, the hunters do not spare even the primates during hunting expeditions, however, most of the people living in these kinds of areas doubt very much the zoonotic link between primate disease to humans, claiming when the meat is well cooked all its infections are killed. It's also good to know that most viruses take advantage of body contact flow trend for effective contamination of victims; hence, the national park conservation authorities must make this education clear to primate bush-meat consumers in some of these areas, a means of prevented viral epidemic disease outbreaks and protecting the primates.

\section{REFERENCE}

[1] Altmann, S. A., and J. Altmann. (1970). Baboon ecology: African field research. University of Chicago Press, Chicago, USA and London, UK.

[2] Arrowood, B.,Trevest, A.,and Mathews, N. (2003). Determinants of day range length in the blacHowler monkey at Lamanai, Belize.J.Trop.Ecol.19:591-594.

[3] Bennett, E. L. (1986).Proboscis Monkeys in Sarawak: Their Ecology, Status, Conservation and Management, World Wildlife Fund Malaysia, Kuala Lumpur, and New York Zoological Society, New York.Google Scholar

[4] BirdLife International (2010). Species factsheet: Eucometis pencillata. Downloaded from BirdLife International on 28 April 2010.

[5] Boutin, S. (1990) Food supplementation experiments with terrestrial vertebrates: patterns, problems and the future. Canadian Journal of Zoology, 68, 203 - 220.

[6] Bronikowski, A. M. \& Altmann, J. (1996). Foraging in a variable environment: weather patterns and the behavioral ecology of baboons. Beh. Ecol. Sociobiol. 39: 11- 25.

[7] Bulte, E. H., and D. Rondeau. 2005. Why compensating wildlife damages may be bad for conservation. The Journal of Wildlife Management 69:14-19. http://dx.doi.org/10.2193/0

[8] Buzzard P.J.(2006). Ecological partitioningvof Cercopithecus campbelli, C. petaurista, and C. diana in the Tai forest. International Journal of Primatology 27:529-558.

[9] Carpentfr, C. R. (1940). A field-study in Siam of the behavior and social relations of the gibbon (Hylobales lar). - Comp. Psychol. Monog. p. 161-212.

[10]Cushman, Fiery Youn g, Liane, and Hauser, Marc (2006). The role of conscious reasoning and intuition in moral judgement: testing three principles of harm, Psychological Science 17: 12, Pg 1082-1089

[11] Chapman, C. A., and C. A. Peres. (2001). Primate conservation in the new millennium: The role of scientists. Evolutionary Anthropology 10:16-33.

[12] Chapman C. A. Chapman L. J.(2000) Determinants of group size in social primates: the importance of travel costs. Pp.24-42 in Group movement in social primates and other animals: patterns, processes and cognitive implications (Boinski S.Garber P., eds.). University of Chicago Press Chicago, Illinois

[13] Chapman, C.A. \& Lambert, J.E. (2000) Habitat alteration and the conservation of African primates: a case study of Kibale National Park, Uganda. American Journal of Primatology, 50, 169 - 186.

[14]Chapman, C. A., S. R. Balcomb, T. R. Gillespie, J. P. Skorupa, and T. T. Struhsaker.(2000). Long-term effects of logging on African primate communities: a 28- year comparison from Kibale National Park, Uganda. Conservation Biology 14:207-217.

[15]Chapman, C. A., A. Gautier-Hion, J. F. Oates, and D. A. Onderdonk. (1999a). African primate communities: Determinants of structure and threats to survival. Pages 1-37 in J. G. Fleagle, C. H. Janson, and K. E. Reed, editors. Primate Communities. Cambridge University Press, Cambridge. 
The Ecological Significance on Primate Activity in Kimbi-Fungom National Park, Northwest Region, Cameroon

[16] Chapman C. A. Wrangham R. W.Chapman L. J. (1995). Ecological constraints on group size: an analysis of spider monkey and chimpanzee subgroups Behavioral Ecology and Sociobiology 36 59-70

[17] Cowlishaw, G. (1998). The role of vigilance in the survival and reproductive strategies of Desert Baboons. Behaviour 135, 431-452.

[18] Cowlishaw G (1997). Trade-offs between foraging and predation risk determine habitat use in a desert baboon population. Anim Behav 53 667-686. Google Scholar Crossref

[19] Daszak, A.A. Cunningham, A.D (2001). Hyatt Anthropogenic environmental change and the emergence of infectious diseases in wildlife Acta Trop., 78 (2001), pp. 103-116

[20] Davies, A.G. (1994) Colobine populations. Colobine Monkeys: Their Ecology, Behaviour and Evolution (eds A.G. Davies \& J.F. Oates), pp. 285 - 310. Cambridge University Press, Cambridge.

[21] De Luca G, Suryapranata H, Zijlstra F, et al.(2003). Symptom-onset-to-balloon time and mortality in patients with acute myocardial infarction treated by primary angioplasty. J Am Coll Cardiol. 2003; 42: 991997.CrossrefMedlineGoogle Scholar

[22] DeFries, R. S., R. A. Houghton, M. C. Hansen, C. B. Field, D. Skole, and J. Townshend. (2002). Carbon emissions from tropical deforestation and regrowth based on satellite observations for the 1980's and 1990's. Proc. Nat. Acad. Sci. 99:14256-14261.

[23]Dickman, A. J. (2010). Complexities of conflict: the importance of considering social factors for effectively resolving human- wildlife conflict. Animal Conservation 13:458-456. http://dx. doi.org/10.1111/j.14691795.2010.00368.x

[24]Distefano, E. 2005. Human-wildlife conflict worldwide: a collection of case studies, analysis of management strategies and good practices. Sustainable Agriculture and Rural Development (SARD), Food and Agricultural Organization of the United Nations (FAO), Rome, Italy. [online] URL: htt p://www.fao.org/sard/common/ecg/1357/en/hwc_final.pdf.

[25] Dunbar, R. I. M. (1993) Socioecology of the extinet theropiths: A modelling approach. In: Theropithecus: The rise and fall of a primate genus, ed. Jablonski, N. G.. Cambridge University Press. [rRIMD] Google Scholar

[26] Ellis, E. C., K. K. Goldewijk, S. Siebert, D. Lightman, and N. Ramankutty. (2010). Anthropogenic transformation of the biomes, 1700 to 2000. Global Ecology and Biogeography 19:589-606

[27]Else, J. G. (1 991). Nonhuman primates as pests. Pages 155-165 in H. O. Box, editor. Primate responses to environmental change. Chapman and Hall, London, UK. http://dx.doi.org/10.1007/978-94-011-3110-0_8

[28] Estrada, A. Raboy, B. E. Oliveira, L. C. (2012) Agroecosystems and primate conservation in the tropics: A review. Am. J. Primatol. 74, 696-711.

[29] Fashing P.J. (2001). Male and female strategies during inter-group encounters in guerezas (Colobus guereza): evidence for resource defence mediated through males and a comparison with other primates. Behavioral Ecology and Sociobiology. 2001;50:219-230. doi: 10.1007/s002650100358. [CrossRef]

[30] Fernandez-Duque, E C. R. Valeggia, S. P. Mendoza (2009). The biology of paternal care in human and nonhuman primates. Annu. Rev. Anthropol. 38, 115-130

[31] Fleagle, J. G. and Gilbert, C. P. (2006). The biogeography of primate evolution: the role of platetectonics, climate and chance. In S. M. Lehman and J. G. Fleagle (eds.), Primate Biogeography, Primate Biogeography (pp. 375-418). New York: Springer.

[32]Fischer, A.G. (1960) Latitudinal variations in organic diversity. Evolution, 14, 64-81.

[33] Ganas, J. \& Robbins, M. M.(2005). Ranging behavior of the mountain gorillas (Gorilla beringei beringei) in Bwindi Impenetrable National Park, Uganda: A test of the ecological constraints model. Behavioral Ecology and Sociobiology 58, 277-288.

[34] Gavilanez, M.M. \& Stevens, R.D. (2013) Role of environmental, historical and spatial processes in the structure of Neotropical primate communi- ties: contrasting taxonomic and phylogenetic perspectives. Global Ecol- ogy and Biogeography, 22, 607-619.

[35] Gillespie, T. R., \& Chapman, C. A. (2001). Determinants of group size in the red colobus monkey (Procolobus badius): An evaluation of the generality of the ecological-constraints model. Behavioral Ecology and Sociobiology, 50, 329-338.

[36] Goodall, J. (1996). The magic I knew as a child. www.isis.csuhayward.edu.

[37] Gouveia, S. F. F. Villalobos, R. Dobrovolski, R. Beltrão-Mendes, S. F. Ferrari (2014), Forest structure drives global diversity of primates. J. Anim. Ecol. 83, 1523-1530

[38] Haddad, N. M Brudvig, L. A. J. Clobert, K. F. Davies, A. Gonzalez, R. D. Holt, T. E. Lovejoy, J. O. Sexton, M. P. Austin, C. D. Collins, C. D. Collins, W. M. Cook,E. I. Damschen, R. M. Ewers, B. L. Foster, C. N. Jenkins, A. J. King, W. F. Laurance, D. J. Levey,C. R. Margules, B. 
The Ecological Significance on Primate Activity in Kimbi-Fungom National Park, Northwest Region, Cameroon

[39] Melbourne, A. O. Nicholls, J. L. Orrock, D.-X. Song, J. R. Townshend (2015), Habitat fragmentation and its lasting impact on Earth's ecosystems. Sci. Adv. 1, e1500052

[40] Hare, B (2011). From hominoid to hominid mind: What changed and why? Annu. Rev. Anthropol. 40, 293309

[41] Hausfater G and Meade B.J (1982). Alternation of sleeping groves by yellow baboons (Papio cynocephalus) as a strategy for parasite avoidance Primates 23: 287-297. Google Scholar Crossref

[42] Heydon, M. J., C. J. Wilson, and T. Tew. (2010). Wildlife conflict resolution: a review of problems, solutions and regulation in England. Wildlife Research 37:731-748. http://d x.doi.org/10.1071/WR10006

[43] Hill C. (2004). Farmers' perspectives of conflict at the wildlife-agriculture boundary: some lessons learned from African subsistence farmers. Hum. Dimen. Wildl 9: 279-286. Google Scholar

[44]Hill R. A. Barrett L. Gaynor D. Weingrill T. Dixon P. Payne H. Henzi S. P. (2003) Day length, latitude and behavioural (in)flexibility in baboons (Papio cynocephalus ursinus) Behavioral Ecology and Sociobiology 53:278-286

[45] Phillips, K. A. Bales, K. L. Capitanio, J. P. Conley, A. Czoty, P. W. B. A. t'Hart, W. D. Hopkins, S.-L. Hu, L. A. Miller, M. A. Nader, P. W. Nathanielsz, J. Rogers, C. A. Shively, M. L. Voytko (2014) Why primate models matter. Am. J. Primatol. 76, 801-827

[46]Hickey, J. R. J. Nackoney, N. P. Nibbelink, S. Blake, A. Bonyenge, S. Coxe, J. Dupain, M. Emetshu, T. Furuichi, F. Grossmann, P. Guislain, J. Hart, C. Hashimoto, B. Ikembelo, O. Ilambu, B.-I. Inogwabini, I. Liengola, A. L. Lokasola, A. Lushimba, F. Maisels, J. Masselink, V. Mbenzo, N. M. Mulavwa, P. Naky, N. M. Ndunda, P. Nkumu, V. Omasombo, G. E. Reinartz, R. Rose, T. Sakamaki, S. Strindberg, H. Takemoto,A. Vosper, H. S. Kühl,(2013) Human proximity and habitat fragmentation are key drivers of the rangewide bonobo distribution. Biodivers. Conserv. 22, 3085-3104

[47] Higham, J.P. MacLarnon, A.M., Heistermann, M., Ross, C. \& Semple, S. (2009). Self-directed behaviours and faecal glucocorticoid levels are not correlated in female wild olive baboons. Stress 12: 526-532

[48] Holenweg, A.-K.;Noë, R.;Schabel, M. (1996). Waser's gas model applied to associations between red colobus and diana monkeys in the Taï National Park, Ivory Coast.Folia Primatol., 67: 125-136.Google Scholar

[49] Isbell L. A.Young T. P.. (1993). Social and ecological influences on activity budgets of vervet monkeys, and their implications for group living. Behavioral Ecology and Sociobiology 32:377-385

[50] IUCN (International Union for the Conservation of Nature and Natural Resources). (2010). Red List of threatened species - version 2010.4. Cambridge, UK. [online] URL: http://www.i ucnredlist.org.

[51] Jaman, M. F. Huffman M. A. (2016), The effect of urban and rural habitats and resource type on activity budgets of commensal rhesus macaques (Macaca mulatta) in Bangladesh. Primates 54, 49-59

[52] Janson C. H Goldsmith M. L. (1995). Predicting group size in primates: foraging costs and predation risks. Behavioral Ecology and Sociobiology 6: 326-336

[53] Krief, S. M. Cibot, S. Bortolamiol,A. Seguya, J.-M. Krief, S. Masi,(2014). Wild chimpanzees on the edge: Nocturnal activities in croplands. PLOS ONE 9, e109925.

[54] Korstjens AH, (2001). The mob, the secret sorority, and the phantoms. Utrecht: Utrecht. Google Scholar

[55]Lehman, S.M. \& Fleagle, J.G. (2006) Primate biogeography: a review. Pri- mate Biogeography: Progress and Prospects (eds S.M. Lehman \& J.G. Fleagle), pp. 1-58. Springer, New York, New York, USA.

[56] Li Z, Rogers M (2005) Habitat quality and range use of white-headed langurs in Fusui, China. Folia Primatol 76:185-195

[57] Marsh, L. K. 2003. The Nature of Fragmentation. Pages 404 in L. K. Marsh, editor. Primates in Fragments: Ecology and Conservation. Kluwer Academic/Plenum Publishers, New York.

[58] Marsh, L.K. \& Chapman, C.A. (2013) Primates in Fragments: Complexity and Resilience. Springer, New York, New York, USA.

[59] Matsuda T, Kuramata M, Takahashi Y, Kitagawa E, Youssefian S, Kusano T (2009) A novel plant cysteinerich peptide family conferring cadmium tolerance to yeast and plants. Plant Signal Behav 4(5):419-21

[60] McGraw WS, (2000). Positional behavior of Cercopithecus petaurista. Int J Primatol 21 157-182. Google Scholar

[61] McKey, D.B. (1978) Soils, vegetation, and seed-eating by black colobus monkeys. The Ecology of Arboreal Folivores (ed. G.G. Montgomery), pp. 423 - 437. Smithsonian Institution Press, Washington, DC.

[62] Meijaard, E. S. Wich, M. Ancrenaz, A. J. Marshall (2012), Not by science alone: Why orangutan conservationists must think outside the box. Ann. N. Y. Acad. Sci. 1249, 29-44

[63] Meijaard, E. D. Buchori, Y. Hadiprakarsa, S. S. Utami-Atmoko, A. Nurcahyo, A. Tjiu, D. Prasetyo, L. C. Nardiyono, M. Ancrenaz, F. Abadi, I. N. G. Antoni, D. Armayadi, A. Dinato, P. G. Ella, T. P. Indrawan, C. 
M. Kussaritano, C. W. P. Priyono, Y. Purwanto, D. Puspitasari, M. S. W. Putra, A. Rahmat, H. Ramadani, J. Sammy, D. Siswanto, M. Syamsuri, N. Andayani, H. Wu, J. A. Wells, K. Mengersen (2011), Quantifying killing of orangutans and human-orangutan conflict in Kalimantan, Indonesia. PLOS ONE 6, e27491

[64] Mercer, B. (2017). Tropical Forests: A Review (The Prince's Charities' International Sustainability Unit,

[65] Milton, K. (1979) Factors influencing leaf choice by howler monkeys: a test of some hypotheses of food selection by generalist herbivores. American Naturalist, 114, $363-378$.

[66] Mittermeier, R. A., Rylands, A. B., and Wilson, D. E. (2013). Handbook of the Mammals of the World. Barcelona: Lynx Edicions.

[67] Mittermeier, R. A., and D. L. Cheney. (1987). Conservation of primates and their habitats. Pages 477-490 in B. B. Smuts, D. L. Cheney, R. Seyfarth, R. W. Wrangham, and T. T. Struhsaker, editors. Primate Societies. Chicago University Press, Chicago.

[68] Oates JF (1987). Food distribution and foraging behavior. In Primate Societies (Smuts BB, Cheney DL, Seyfarth RM, Wrangham RW, Struhsaker TT, eds.), pp 197-209. Chicago, The University of Chicago Press.

[69] Oates, J.F., Whitesides, G.H., Davies, A.G., Waterman, P.G., Green, S.M., Dasilva, G.L. \& Mole, S. (1990) Determinants of variation in tropical forest primate biomass: new evidence from West Africa. Ecology, 71, $328-343$.

[70] Olupot, W. 2000. Mass differences amoung male mangabey monkeys inhabitting logged and unlogged forest compartments. Conservation Biology 14:833-843.

[71] Ostro, 1. E. T., S. C. Silver, F. W. Koontz, T. P. Young, and R. H. Horwich. (1999). Ranging behavior of translocated and established groups of black howler monkeys (Aloutta pigra) in Belize, Central America. Biological Conservation 87:181-190.

[72] Peres. C.A. (1993). Structure and spatial organization of an Amazonian terra firme primate community. $J$. Trop. Ecol. 9:259-276.

[73] Robbins, M. M., \& McNeilage, A. (2003). Home range and frugivory patterns of mountain gorillas in Bwindi Impenetrable National Park, Uganda. International Journal of Primatology, 24, 467-491.

[74] Silveira, J. M. J. Louzada, J. Barlow, R. Andrade, L. Mestre, R. Solar, S. Lacau, M. A. Cochrane ,(2016) A multi-taxa assessment of biodiversity change after single and recurrent wildfires in a Brazilian Amazon forest. Biotropica 48, 170-180

[75] Sponsel, L.E., N. Ruttanadakul, and P. Nadadecha-Sponsel. (2002). "Monkey business? The conservation implications of macaque ethnoprimatology in Southern Thailand," In Primates Face to Face: The Conservation Implications of Human-Nonhuman Primates Interconnections. Edited by A. Fuentes and L.D. Wolfe, pp. 288-309. Cambridge: Cambridge University Press.

[76] Stevenson PR (2006) Activity and ranging patterns of Colombian woolly monkeys in North-Western Amazonia. Primates 47:239-247

[77] Strier, K. B. (2007). Primate Behavioral Ecology. Boston, MA: Allyn and Bacon. Harvey, P.H. \& Clutton-Brock, T.H. (1981) Primate home-range size and metabolic needs. Behavioral Ecology Sociobiology,8, $151-155$.

[78] Strum, S. C. (2010). The development of primate raiding: Implications for management and conservation. International Journal of Primatology, 31, 133-156.CrossRefPubMedPubMedCentralGoogle Scholar

[79] Sussman R. W. (1991). Primate origin and evolution of angiosperms. American Journal of Primatology, 23, 209-233

[80] Tata, F.T. (2015): The Kimbi-Fungom National Park; -A situation report. Green works company Ltd. P.O. Box, Bamenda, Cameroon<bankomtata@yahoo.com>.

[81] Terborgh, J. (1985) The vertical component of plant species diversity in temperate and tropical forest. The American Naturalist, 126, 760-776.

[82] Treves A (2002). Predicting predation risk for foraging, arboreal primates. In: Eat or be Eaten: Predator Sensitive Foraging Among Primates. L. E. Miller (ed.), pp.222-241. Cambridge University Press, Cambridge. Google Scholar

[83] Treves, A., Drescher, A., \& Ingrisano, N. (2001). Vigilance and aggregation in black howler monkeys (Alouatta pigra).Behavioral Ecology and Soci-obiology 50, 90-95

[84] Vargas, A., I. Jimenez, F. Palomares, and M. J. Palacios. (2002). Distribution, status, and conservation needs of the golden-crowned sifaka (Propithecus tattersalli). Biological Conservation 108:325-334.

[85] Wrangham R. Gittleman J. L. Chapman C. A.(1993). Constraints on group size in primates and carnivores, population density and day-range as assays of exploitation competition. Behavioral Ecology and Sociobiology32: 199-209

[86] Wright, D.H. (1983) Species-energy theory: an extension of species-area theory. Oikos, 41, 496-506. 
The Ecological Significance on Primate Activity in Kimbi-Fungom National Park, Northwest Region, Cameroon

[87] Woodward, F.I. (1987) Climate and Plant Distribution. Cambridge Univer- sity Press, Cambridge.

[88] Woodroffe, R., S. Thirgood, and A. Rabinowitz, editors. 2005. People and wildlife: conflict or coexistence? Cambridge University Press, Cambridge, UK.

[89] Wolters S, Zuberbühler K, (2003). Mixed-species associations of Diana and Campbell's monkeys: the costs and benefits of a forest phenomenon Behaviour140 371-385.

[90] Yang Z. PAML 4: Phylogenetic analysis by maximum likelihood. Mol Biol Evol. (2007).;24:1586-1591. [PubMed]

[91]Zhou X, . Zhou X, Su Z, Anishkin A, Haynes WJ, Friske EM, Loukin SH, Kung C, Saimi Y (2007) Yeast screens show aromatic residues at the end of the sixth helix anchor transient receptor potential channel gate. Proc Natl Acad Sci U S A 104(39):15555-9

[92]Zinner, D., Knogge, C., Heymann, E. W., \& Kappeler, P. M. (2001). Large primate aggregations: Limits to female-female networks? Primate Report, 60, 47-48.

[93]Zuberbühler K, \& Jenny D, (2002). Leopard predation and primate evolution. J Human Evol 43 873-886.

Citation: Melle Ekane Maurice, et.al (2020). "The Ecological Significance on Primate Activity in KimbiFungom National Park, Northwest Region, Cameroon ". International Journal of Research Studies in Zoology (IJRSZ), vol. 6, no. 2, pp. 1-14, 2020. Available: DOI: http://dx.doi.org/10.20431/2454-941X.060201

Copyright: () 2020 Authors. This is an open-access article distributed under the terms of the Creative Commons Attribution License, which permits unrestricted use, distribution, and reproduction in any medium, provided the original author and source are credited. 